\title{
Reservoir inflow pattern and its effects on hydroelectric power generation at the Kainji Dam, Niger State, Nigeria
}

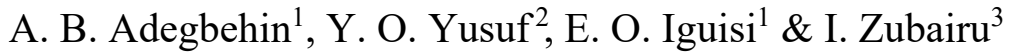 \\ ${ }^{1}$ Department of Geography, Ahmadu Bello University, Nigeria \\ ${ }^{2}$ Deparment of Geography, Federal University Gashua, Nigeria \\ ${ }^{3}$ Department of Remote Sensing, Cartography and GIS, \\ Kaduna Polytechnic, Nigeria
}

\begin{abstract}
The focus of this empirical study is to investigate the effect of reservoir inflow pattern on hydroelectric power generation in Kainji dam, Niger state, Nigeria. Investigation was conducted using data on reservoir inflow and the amount of power generated for the period of thirty years (1985-2014) from Kainji hydropower station. The trends of reservoir inflow for the time frame of study were shown using trend lines. Hypothesis was tested for the relationship between reservoir inflow and the amount of power generated using Pearson correlation coefficient. Analyses on periods with high and low inflow on the amount of power generated was achieved by getting the overall mean of power generated for the time frame of study while comparison was made on the mean monthly power generated and inflow pattern using a trend analysis. The study reveals that the low inflow period in Kainji reservoir is between April and July of each year, with an average inflow of $200 \mathrm{~m}^{3} / \mathrm{sec}$ to $600 \mathrm{~m}^{3} / \mathrm{sec}$ with May, June and July having below $500 \mathrm{~m}^{3} / \mathrm{sec}$ while the amount of power generated within this period is between $200 \mathrm{mwh}, 179 \mathrm{mwh}$ and $146 \mathrm{mwh}$ respectively. The high inflow period is between September and October with the least month having an average inflow of $2700 \mathrm{~m}^{3} / \mathrm{sec}$ to $2900 \mathrm{~m}^{3} / \mathrm{sec}$. This season generates a minimum of $220 \mathrm{mwh}$ and $232 \mathrm{mwh}$. The reservoir inflow pattern shows a decreasing trend, while it exhibits fluctuations at various levels. The research indicated that reservoir inflow has a strong relationship on the amount of power generated with
\end{abstract}


a correlation coefficient of 0.92 . It was recommended that the government should encourage the use of other alternative sources of electricity generation in order to meet the growing demand in electricity.

Keywords: reservoir inflow, power generation, high inflow period, low inflow period, black flood, white flood, Kainji Dam.

\section{Introduction}

Water is a transparent fluid which forms the world's streams, lakes, oceans and ground water. It is also the major constituent of the fluids in all living things (Gleick [1]).Water is a liquid at standard ambient temperature and pressure, but it often co-exists on Earth with its solid state, ice; and gaseous state, steam (water vapour). Water on earth moves continually through the water cycle by evaporation, transpiration (evapotranspiration), condensation, precipitation, and runoff, usually reaching the sea. Evaporation and transpiration contribute to the precipitation on land (United Nations Environmental Programme (UNEP) [2]).

Generating hydro electricity, water must be in motion. This is kinetic (moving) energy. When flowing water turns blades in a turbine, the form is changed to mechanical (machine) energy. The turbine turns the generator rotor which then converts this mechanical energy into another energy form, which is electricity. Since water is the initial source of energy, we call this hydroelectric power. Reservoir inflow is important in the generation of electricity, it refers to the amount of water entering a reservoir expressed in cubic meter per second, water reservoirs are made to provide multiple benefits, like flood control, stabilize electricity through proper management of reservoir peak inflow, average outflow, discharge, and minimum inflow. Also in many cases, reservoirs provides domestic, drinking and industrial water supply for man (United State Department of the Interior [3]).

Globally, hydropower is a very significant contributor to energy systems. Large dams became a prominent instrument for economic development in the past century, as the number of large dams stood at 5000 around the $1950 \mathrm{~s}$ (International Commission on Large Dams (ICOLD) [4]). Nigeria is endowed with abundant water resources and it is clear that the country is blessed with a huge hydropower potential (Okoro [5]). Kainji dam construction was carried out by Impregilo (a consortium of Italian Civil Engineering Contractors). It began in 1964 and was completed in 1968. Most of the structure is made from earth, but the centre section, housing the hydroelectric turbines, was built from concrete. This section is 65 metres high. Kainji dam is one of the longest dams in the world. The Nigerian government has invested a lot in the dam. It was designed to have a generating capacity of 960 Megawatts; however, only 8 of its 12 turbines have been installed, reducing the capacity to 760 Megawatts. This might be another reason for the epileptic power supply experienced in the country (Ifabiyi [6]). 


\subsection{Research problem}

Between 2007 and 2035, worldwide energy consumption is projected to double (John and James [7]). Scientists predict that the global population will swell to over 10 billion by 2050 . Our current population is already taxing current energy and water resources. These demands will grow with the global population. The next forty years promise to challenge energy and water resource management. Hydropower is one response to these challenges; in many areas of the world. Dams provide energy and regulate water supply. Each region of the globe faces unique challenges as our climate changes. Floods, droughts, rapids glacial melt, increasing temperatures and variability in timing, location and amount of precipitation are all symptoms of climate change that will affect hydroelectric generation by increasing water resources and hydropower potential in some regions, diminishing them in others. Though all nations are susceptible to effects of global climate change, developing countries are inherently more vulnerable to the effects of climate change disruptions because they have fewer disposable resources to spend on unexpected extreme weather events and on adapting to long-term alteration (John and James [7]).

In Nigeria, rainfall takes the centre stage from the birth of a new year moving from the southern to the northern part in late May and June. The northern part of Nigeria has the lowest amount of rainfall. The peak of rainy season in most parts of Nigeria occur in August with more than enough for South as well as part of the Northern region of the country (Okoro [5]). After the rain, comes the dry season, which is mostly experienced in the northern parts of the country, wells and rivers are dried up, thereby reducing the water in the reservoir of many rivers which in the long run would diminish dam electrical output (Okoro [5]).

Many scholars have carried out studies on climate related issues on hydro power stations, all aimed at proffering solutions to meet the challenging increasing demand in electricity, some of which are Mcnally [8], who worked on hydropower vulnerability caused by climate change impacts in the Mekong River located in South Asia. The study revealed that climate change affects evaporation rates, annual river discharge, precipitation, and glacial melt. Buyansi [9] also worked on the vulnerability of hydro-electric energy resources in Kenya due to climate change and it was observed that the major challenges experienced in the hydro power station is high fluctuating river flows, sediment laden floods, scarce sporadic precipitation and extreme transpiration rate. Salami and Olukanni [10] carried out assessment and impact of hydropower dam reservoirs outflow on the downstream river flood regime in Nigeria. The study revealed that the sudden release of flood water is not due to normal operation at the hydropower stations in Nigeria, but is due to sudden discharges at the reservoirs located in the Niger Republic and the Republic of Mali. This leads to excess releases at Kainji in order to create enough space for the incoming flood water. This automatically forces the release of water at Jebba and thus creating flood problem downstream.

Similarly, Abdul-Aziz [11] worked on the nature and implication of water level fluctuations in Shiroro dam, Niger state. The study revealed that Shiroro 
dam causes loss of farmlands to those riparian communities that farm in water channels believed to be fertile for cultivation. It also shows that stability of agricultural activity depends on seasons and the crops produced. Salami et al. [12] worked on the assessment of climate variability on Kainji hydropower reservoir, Niger State, Nigeria, using reservoir inflow data from (1970-2003) from Kainji hydropower station. They found out that there is slight decrease in reservoir inflow, which may lead to shortage of water for hydropower generation in future. The study is related to this work. However, this research is aimed at investigating the situation by utilizing data from 1985 to 2014 . This will help to get a more recent conclusion and remove ambiguity by relating reservoir inflow to the hydroelectric power generated in the Kainji reservoir, Niger state, Nigeria. The objectives are to determine the trend of reservoir inflow pattern, analyze the periods of high and low inflow and the amount of power generated and examine the effect of reservoir inflow patterns on amount of power generated from 1985 to 2014 while the hypothesis is that there is no significant relationship between reservoir inflow pattern and hydroelectric power generation.

\section{Study area}

The study area is the Niger River. The river is the principal river of Western Africa extending about $4,180 \mathrm{~km}$. Its drainage basin is $2,117,700 \mathrm{~km}^{2}$ in area. The river extends from Latitudes $10^{\circ} 00^{\prime} \mathrm{N}$ to $15^{\circ} 00^{\prime} \mathrm{N}$ and Longitudes $5^{\circ} 00^{\prime} \mathrm{W}$ to $5^{\circ}$ $00^{\prime} \mathrm{E}$. The Niger River is the third-longest river in Africa. Its source is in the Guinea highlands in the south-eastern Guinea, and runs in a crescent through Mali, Niger, on the border of Benin and through Nigeria (see Fig. 1). However Kainji reservoir is the main focus. The Kainji reservoir is across the Niger River in Niger State of Nigeria. The reservoir is located on latitude $10^{\circ} 08^{\prime} \mathrm{N}$ and longitude $4^{\circ} 37^{\prime} \mathrm{E}$ (see Fig. 2). Kainji Lake extends for about 10 kilometres, including its saddle dam, which closes off a tributary valley. The primary section across the outflow to the Niger River is $550 \mathrm{~m}$ long.

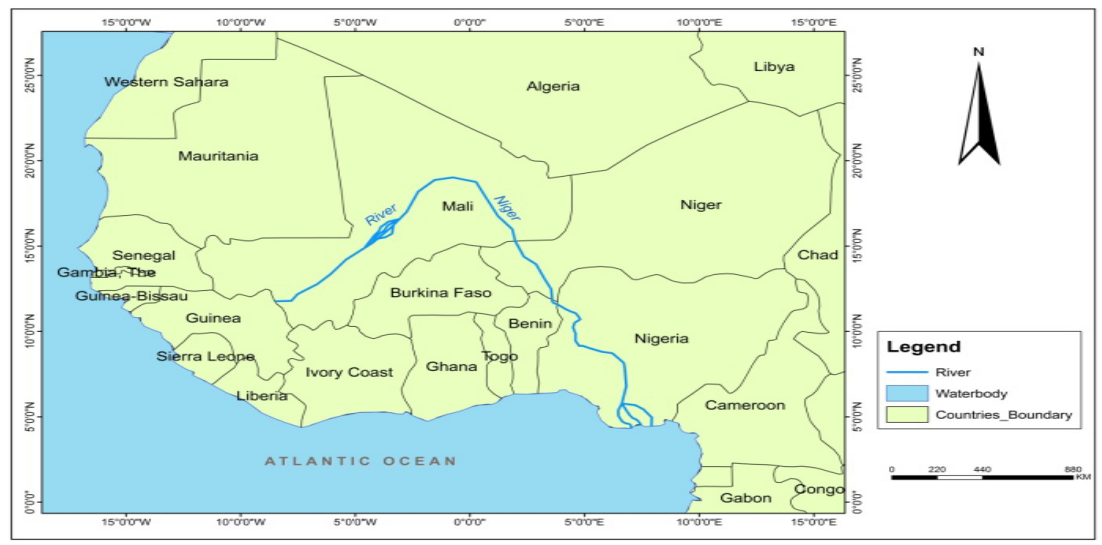

Figure 1: River Niger (source: modified from World Map). 


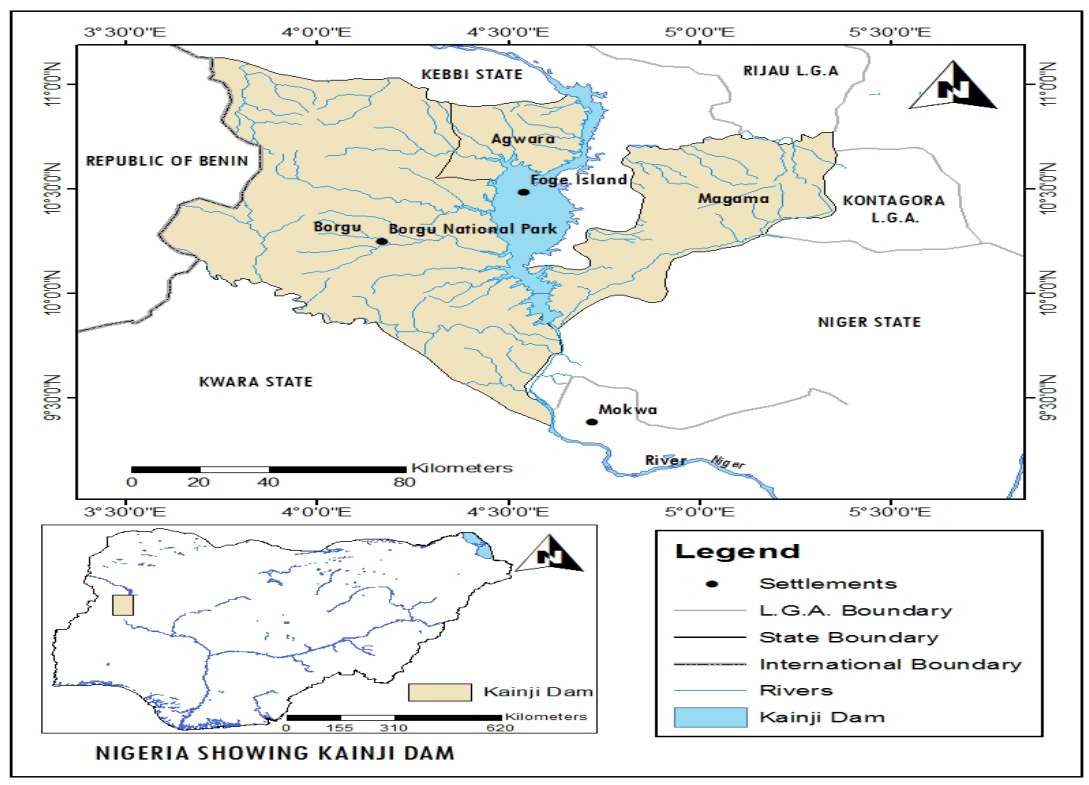

Figure 2: Niger state showing Kainji reservoir (source: modified from Nigerian administrative map).

The basin is characterized by savanna climate. The months of April to October are rainy with maritime air blowing from the south. The months of November to march are on the other hand dry with Saharan air from the north. The chief features of the climate are the result of a transition in climatic factors between the northern area with a single peak rainfall regime and a southern zone which has a well-defined dual peak regime. The climate is described as hot equatorial with high maximum temperatures and an average daily maximum of $33.5^{\circ} \mathrm{C}$ in the warmest month while the mean annual temperature is about $30^{\circ} \mathrm{C}$. The months of April and May are the hottest month while December and January are the coldest (Okoro [5]). The lake basin area is a broad alluvial valley with rock formation of the Pre Cambrian basement complex which forms series of rapids. The relief of the reservoir is seen to resemble a valley lake with a middle enlargement (Imevbore and Visser [13]).

The vegetation in the area consists of a mixture of grass and woodlands and belongs to the Northern Guinea savanna type. The soil cover of the lake bed is rather variable in composition, ranging from stony to sandy or from loam and clay-loam to clay in the land bordering the river throughout the lake area, while the river bedrock is covered by a layer of coarse to medium sand of a variable thickness, fine sand and clay (Orire [14]). The average maximum discharge of the River Niger is between 6000 and $8000 \mathrm{~m}^{3} / \mathrm{sec}$ and this occurs during the months of September and October when the white flood dominates the river. A subsidiary flood, the black flood arising from conditions outside Nigeria, Reaches the reservoir area around December and exerts a noticeable effect on the 
discharge $\left(1750 \mathrm{~m}^{3} / \mathrm{sec}\right)$. The lowest flow occurs during the month of June $\left(500 \mathrm{~m}^{3} / \mathrm{sec}\right)$, At this time great portions of the river bed are dry and fields of sand and are exposed (Orire [14]).

The Kainji lake region covers three emirates, Borgu in the former Ilorin province, Kontagora in the former Niger province and Yauri in the former Sokoto province. According to National Population Commission [15], the entire region has an estimates population of 172,835 and is projected to have a population of about 296,756 in 2014 . The region is occupied by twelve different ethnic groups. The ethnic groups can be divided broadly into two, the riverine and the lowland (Orire [14]).

\section{Methodology}

A survey of the study area was carried out in order to get the researchers acquainted with the study area and the data required for the study. The amount of power generated, reservoir inflow data for the period of study was gotten from the Kainji hydropower station.

Determination of the trend of reservoir inflow patterns in the study area was achieved by using trend analysis. The mean for each variable for each year was first computed to actualize this. Analyzing the period of high and low inflow and the amount of power generated in this period was achieved by getting the overall mean of power generated for the time frame of study (1985-2014) while comparison was made on mean monthly power generated on inflows pattern using trend analysis while examination of the effect of reservoir inflow pattern on amount of power generated was achieved using Pearson correlation coefficient

\section{Results and discussion}

\subsection{Trend of reservoir inflow}

The reservoir inflow data collected from the study area was computed to show the pattern of reservoir inflow for the time frame of study. The aim was to find out if reservoir inflow in the area is actually increasing or decreasing.

In Fig. 3, the reservoir inflow pattern fluctuating though the inflow shows a decreasing trend for the time frame of study and this decrease could be attributed to the establishment of infrastructures upstream and climate change, caused from within and out of the country. It is important to note that reservoir inflow in Kainji dam is a major factor that determines the amount of power generated because precipitation and flows covering 4,000 km and over nine countries across West Africa is being received at the dam.

The study reveals that the reservoir inflow exhibits a negative trend though with various degrees of fluctuation from the year 1985 to 1993, with an increase in 1994 and a sudden decrease in 1999 while year 2000 to 2014 exhibit tremendous fluctuation at various levels. 


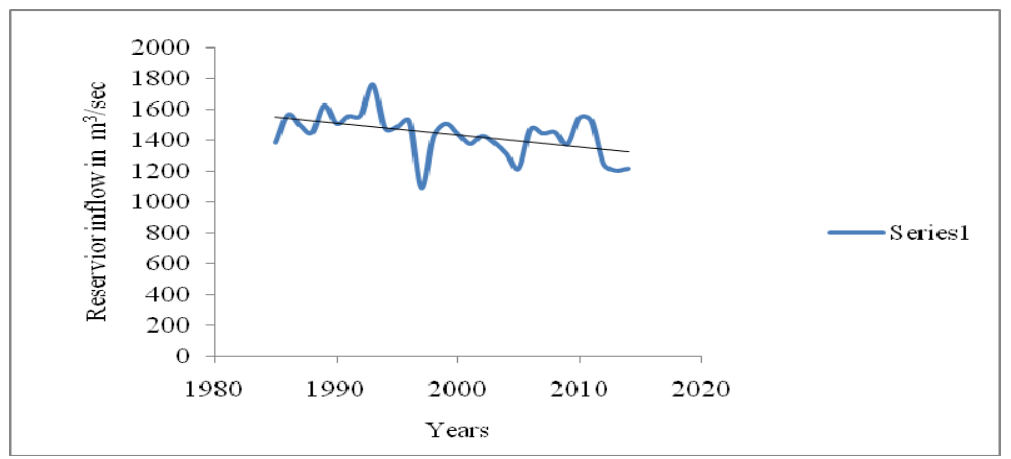

Figure 3: Trend of reservoir inflow in Kainji HEP station from 1985-2014 (source: field survey, 2015).

\subsection{Quantification of amount of power generated}

The amount of power generated within the last thirty years in the study area was collated. The overall mean of power generated for the time frame of study was gotten while the mean monthly power generated within the time frame of study was use to compare the amount of power to the amount of inflow received at monthly basis in the reservoir. The mean monthly power generated was gotten after analyzing the amount of power generated data collected from the study and used to plot the graph below in which the trend that the power generated for each month annually follows, which is a resultant effect of the variation in the intensity of the inflow experienced in the reservoir over the years. Below is the mean monthly power generated (Fig. 4).

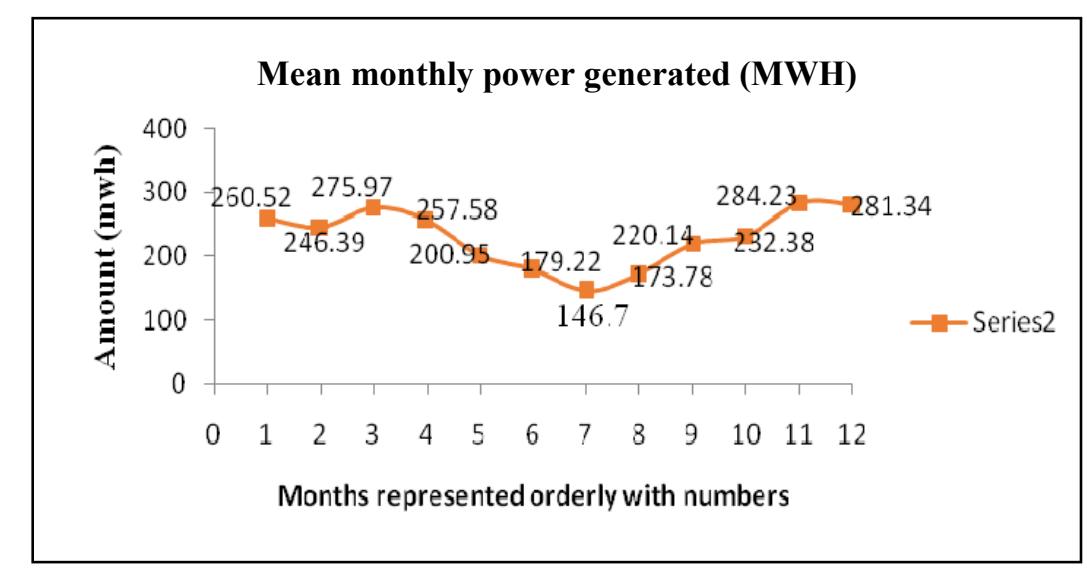

Figure 4: The mean monthly power generated from 1985-2014 in Kainji dam (source: field survey, 2015). 
In Fig. 4, various degrees of fluctuation can be observed. January, February, March and April with an average mean of 260.52mwh, 246.39mwh, 275.9mwh and $257.58 \mathrm{mwh}$ respectively have high amount of power generated. While, the month of May with $200.95 \mathrm{mwh}$ marks the period of decline in the amount of power generated to the month of July with an average of $146.7 \mathrm{mwh}$ which is the lowest as the study reveals. Although, the month of June generates $179.22 \mathrm{mwh}$ while the month of August with a mean of 173.78 mwh marks the period of increase in power generation and this increase continues to December with September, October, November and December having an average of $220.14 \mathrm{mwh}, 232.38 \mathrm{mwh}, 284.23 \mathrm{mwh}$ and $281.34 \mathrm{mwh}$ respectively.

This is so because of the inflow pattern of the Kainji reservoir which is as a result of the river flow regime characterized by two distinct flood periods occurring annually, namely the white and black floods. The black flood derives its flow from the tributaries of the Niger outside Nigeria (flows from OctoberMay, though the flow will have been drastically reduced in May). It arrives Kainji reservoir in November while the White flood is a consequent of flows from local tributaries especially the Sokoto-Rima and Malendo River systems. The White flood is heavily laden with silts and other suspended particles (flows from June to September) and arrives Kainji in August.

The low flow period in Kainji reservoir is between April and July of each year and April is the beginning of the wet season period in the study area. This must have contributed to the low amount of power generated during the April to July period. Fig. 5 further shows the mean monthly inflow to the Kainji reservoir observed from field analysis.

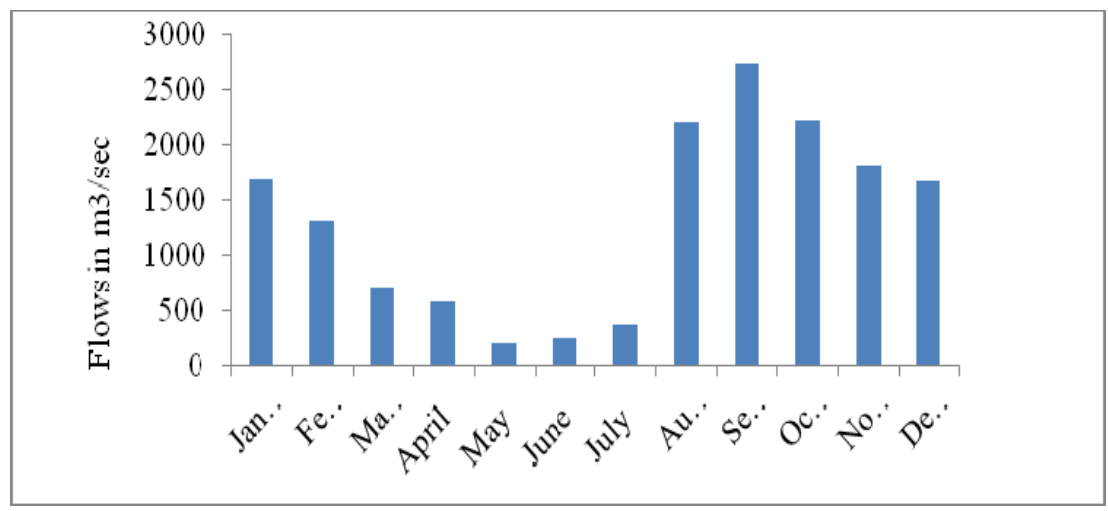

Figure 5: Mean monthly inflow to the reservoir (source: field survey, 2015).

Jimoh [16] carried out research on the monthly inflow in Kainji Reservoir in 2008 and observed similar result and this further substantiates the accuracy of this research investigation. 


\subsection{Comparison of amount of power generated and inflow pattern in the reservoir}

Looking at Figs 4 and 5, a lot of relationship exist. Months with high inflows generate more power while those with low inflow generate lower output. This simply means an increase in one leads to an increase in the other and vice-versa. This is evident from the month August having inflow of $2200 \mathrm{~m}^{3} / \mathrm{sec}$ which generates $173.78 \mathrm{mwh}$, September with 2900 inflow in $\mathrm{m}^{3} / \mathrm{sec}$ generates $220.14 \mathrm{mwh}$, October with 2400 inflow in $\mathrm{m}^{3} / \mathrm{sec}$ generates $232.38 \mathrm{mwh}$, November with 1800 inflow in $\mathrm{m}^{3} / \mathrm{sec}$ generates $284.23 \mathrm{mwh}$, December with 1700 inflow in $\mathrm{m}^{3} / \mathrm{sec}$ generates $281.34 \mathrm{mwh}$, January with 1600 inflow in $\mathrm{m}^{3} / \mathrm{sec}$ generates $260.52 \mathrm{mwh}$, February with 1400 inflow in $\mathrm{m}^{3} / \mathrm{sec}$ generates $246.39 \mathrm{mwh}$, March 700 inflow in $\mathrm{m}^{3} / \mathrm{sec}$ generates $275.97 \mathrm{mwh}$, April with 500 inflow in $\mathrm{m}^{3} / \mathrm{sec}$ generates 257.58 while May with an inflow of $200 \mathrm{~m}^{3} / \mathrm{sec}$ generates $200.95 \mathrm{mwh}$ June $200 \mathrm{~m}^{3} / \mathrm{sec} 179.22 \mathrm{mwh}$ and July $358 \mathrm{~m}^{3} / \mathrm{sec}$ with $146.7 \mathrm{mwh}$ Although there might be other factors also contributing to this phenomena.

\subsection{Relationship between reservoir inflow and amount of power generation}

The relationship between reservoir inflow and amount of power generated from the study area was analyzed using Pearson correlation coefficient.

Table 1: Relationship between reservoir inflow and amount of power generated.

\begin{tabular}{|c|c|c|c|}
\hline \multicolumn{4}{|c|}{ Correlations } \\
\hline & & $\begin{array}{c}\text { Reservoir } \\
\text { inflow. }\end{array}$ & Elect. Gen \\
\hline \multirow[t]{3}{*}{ R.I (V1) } & Pearson C. & 1 & 0.92 \\
\hline & Sig. (1-tailed) & & 0.01 \\
\hline & $\mathrm{N}$ & 30 & 30 \\
\hline \multirow[t]{3}{*}{ E.G(V2) } & Pearson Correlation & 0.92 & 1 \\
\hline & Sig. (1-tailed) & 0.01 & \\
\hline & $\mathrm{N}$ & 30 & 30 \\
\hline
\end{tabular}

Source: field survey, 2015.

Table 1 shows the relationship between the reservoir inflow and electricity in the study area. The $r$ value is 0.92 and this is close to 1 , indicating a strong relationship, though Fig. 3 above shows that reservoir inflow pattern has been fluctuating but decreasing in the trend for the time frame of study and this decrease could be attributed to climate change, caused from outside and within Nigeria. Similarly, (Salami et al. [12]) reveal that the reservoir inflow at Kainji exhibited negative trends, which indicate a tendency to decrease even though insignificant. They noted that the slight decrease in the reservoir inflow might be due to development of infrastructures at the upstream of Kainji reservoir and 
concluded that there is a negative impact of climate change on the water resources in the study area due to slight decrease in reservoir inflow.

Jimoh [16] also reveals that reservoir inflow in Kainji dam is a major factor that determines the amount of power generated because precipitation and inflow covering $4,000 \mathrm{~km}$ and over nine countries across West Africa is being received at the dam. Fig. 4 shows that months of August, September, October, November, December, January, February and March who receive high inflow as a result of the white and black floods generate more electricity than months of April to July whose inflow are lower.

\section{Conclusion and recommendations}

\subsection{Conclusion}

The reservoir pattern and power generated data in Kainji reservoir was subjected to various analyses. The trends of the parameter for the time frame of study were shown using trend line. The reservoir inflow pattern shows a decreasing trend. Though it exhibit fluctuations at various levels while statistical analysis revealed that there is increase in power generation from the month of August to March. While the low inflow season is between April and July this might be as a result of the river flow regime characterized by two distinct flood periods occurring annually, namely the white and black floods.

The black flood derives its flow from the tributaries of the Niger outside Nigeria (flows from October-May, though the flow will have been drastically reduced in May). It arrives at Kainji reservoir in November while the White flood is a consequent of flows from local tributaries especially the Sokoto-Rima and Malendo River systems. The White flood is heavily laden with silts and other suspended particles (flows from June to September) and arrives Kainji in August.

Lastly, the hypothesis was tested for relationship on reservoir inflow and the amount of power generated using Pearson correlation coefficient. The result of the research indicated that reservoir inflow with $r$ value of 0.92 have strong relationship with the amount of power generated.

\subsection{Recommendations}

Sequel to the findings of this study, the following recommendations became imperative.

1. The study reveals that Kainji reservoir experience inflow throughout the year, as a result of annual white and black floods. So if the government increases the water carrying capacity of the reservoir or probably finds a means of storing water, electricity output in the periods of low inflow will increase, as their will be enough water to produce electricity.

2. The government should carry out comprehensive review of existing national water resources master plan. The new plan should seriously 
consider recent phased development and management of identifiable problems. While a financial plan, should be adopted in setting out annual budgetary allocations to relevant water development and energy projects.

3. The Nigerian government should try to install the remaining 4 turbines in Kainji reservoir, thereby increasing the number of the turbines in the station from 8 to 12 turbines as initially designed. They should also consider constructing other hydropower dams where applicable, this will help to increase the amount of electricity generation in the country.

4. The government should encourage the use of other alternative sources of electricity generation in order to meet the growing demand in electricity. Other alternative sources like the wind mill, in place windy in the country, solar and nuclear power plant should be widely supported.

\section{References}

[1] Gleick, P.H. (Ed). Water in Crisis: A Guide to the World's Freshwater Resources. Oxford University Press. Pg.13, 1993

[2] UNEP, Vital Water Graphics: An Overview of the State of the World's Fresh and Marine Waters. United Nations Environmental Programme. http://www.unep.org/vitalwater [Accessed 11 August 2006], 2002

[3] USDT, Hydroelectric Power. US Department of the Interior, Bureau of Reclamation Power Resource. Available at http://www.usbr.gov/power /edu/pamphlet.com 2005

[4] ICOLD, World Register of Dams, Paris, International Commission on Large Dams. Available online at www.ga.gov.au 1998

[5] Okoro, M.C., Rivers in Nigeria and Corresponding Hydro Potential. Proceedings of Conference on National Workshop Capacity Building in Small River Planning and Design for isolated off-grid Electricity Generation. Nigeria pp. 82-87, 2006

[6] Ifabiyi, I.P., Contributions of Reservoir Elements to Monthly Electricity Generation in the Jebba Hydropower Reservoir, Nigeria. Journal of Applied Sciences, Vol. 2, pp. 251-263, 2011

[7] John, C.J. and James, T.T., Annual Energy Outlook. United States Energy Information Administration. Available from www.eia.gov/forecasts/aeo 2011

[8] Mcnally, A.D., Hydropower and Sustainability: Resilience and Vulnerability in China's Power Sheds. Journal of Environmental Management, Vol. 90, No. 1: pp. 286-293, 2009

[9] Buyansi, M.M., Vulnerability of Hydro-electric Energy Resources in Kenya due to Climate Change Effects: The case study of the Seven Forks Project. Journal of Agriculture and Environmental Sciences Vol. 1, pp. 36-49, 2012

[10] Salami, A.W. and Olukanni, D.O., Assessment of Impact of Hydropower Dams Reservoir Outflow on the Downstream River Flood Regime Nigeria's Experience Journal of Environmental Hydrology, Vol. 16, No. 2: pp. $62-82,2012$ 
[11] Abdul-Aziz, F.A., The Nature and Implication of Water Level Fluctuations in Shiroro Dam Niger State, Unpublished B.Sc Project, Department of Geography, Ahmadu Bello University, Nigeria, 2014

[12] Salami, A.W., Sule, B.F. and Okeola, O.G., Hydrology for Sustainable Development and Management of Water Resources in the Tropic. Paper presented at the Annual Conference of the National Association of Hydrological Sciences. Abuja, Nigeria, 2011

[13] Imevbore, A.M. and Visser, S.A. (Eds), Some General Features of the Kainji Reservoir Basin: A Nigerian Man Made Lake. Kainji Lake Studies Vol.1 Ecology, Ibadan, Nigerian Institute of Social and Economic Research, pp. 17-26, 1970

[14] Orire, M.A., Effects of the Kainji Dam on the Fishing Industry in the Kainji Lake Area Niger State, Unpublished M.sc thesis, Department of Geography, Ahmadu Bello University Nigeria, 1991

[15] NPC (2009). Population Census of the Federal Republic of Nigeria: Analytical Report at the National Level. National Population Commission retrieved from www.population.gov.ng 2009

[16] Jimoh, O.D., Operation of Hydropower Systems in Nigeria. Department of Civil Engineering Federal University of Technology, Minna Nigeria, 2008 